\section{Afro-American Sociologists And Nepali Ethnography}

\author{
Stephen L. Mikesell
}

\begin{abstract}
Here comes the penalty which a land pays when it stifles free speech and free discussion and turns itself over entirely to propaganda. It does not make any difference if at the time the things abvocated are absolutely right, the nation, nevertheless, becomes morally amasculated and mentally hogtied, and cannot evolve that healthy difference of opinion which leads to the discovery of truth under changing conditions.- W. E. Burghardt Du Bois
\end{abstract}

\section{Introduction}

One need only look at the previous volumes of this journal to note that the development of the sociology and anthropology department in Nepal has been strongly influencedby Euro-Americanscholarsand scholarship.Closerexaminationshows that this influence over the department and the social sciences in Nepal has furthermore been white and, moreover, mostly male. From the perspective of Nepali social scientists, who are somewhat removed from the manner that problems are represented and experienced in the west, this observation may seem to be meaningless. However, even when knowledge presents itself as objective and detached, it has never been a passive observer or disinterested tool in the development of human society. ${ }^{2}$ The acceptance of the disciplines of anthropology and sociology from the United States and western Europe according to the selfunderstandings of these disciplines as they are practiced there, also implies acceptance of their appraisal of the conditions which gave them birth. For social scientists and the people they study these conditions have been ones of colonialism, industrialization imperialism, the deveropment of munopoly capitalism and transnational corforations, embourgeoisiement etc;- processes in $\mathrm{Nepal}$ which are represented and legitimized by the word "development" or bikas In the U.S. and parts of Europe, the representation of these global processes has been interrelated with categories and representations of race and gender. Furthermore, in the United States, the dominant viewpoint is identified with white skin and the male gender-the race and gender catagories with which the dominant group identifies itself, even though many of the people who call themselves white male are not in the dominant class and not all of the dominant clase is white or male. 3

Within the United States the categories of skin color and gender have underlain and permeated the development of the social sciences from their inception in the 19 ih Century, both in the manner that these categories have been addressed by the social sciences and in the manner that the individuals signified by them have been permitted to participate in inteilectual intercourse. Thus, in borrowing from the United States and Western Europe, entire traditions of sociological thought are easily omitted from entering into the discourse of the social sciences in Vepal. Included among these omitted traditions are 
those which have been developed by the oppressed populations of the United Stated-especially the progressive, critical and outspoken voices among them. 4 These include view of AfroAmericans, Native and Hispanic Americans, and women of color. The later category includes women from all these other categories who taken together as the most repressed group, have found that their own problems in large part are not being addressed even within their own "minority" traditions.

In the U. S., these traditions are always prefixed with their minority status, such as black sociology or "women's" anthropology. This serves to denigrate the work and make it appear to be less worthy of consideration.

One device evolved by the whites was to tab whatever the blacks did with the prefix "Negro." We had Negro literature, Negro athletes, Negro politicians, Negro workers. The malignant ingeniousness of this device is that although it accurately described an objective bioloical fact-or at least a sociological fact in America-it concealed the paramount paychological fact; that to the white mind, prefixing anything with "Negro" automatically consigned it to inferior category. A well- known example of the white necessity to deny due credit to blacks is in the realm of music. White musicians were famous for going to Harlem and other Negro cultural centers literally to steal the black man's music, carrying it back across the color line into the Great white world and passing off the watered-down loot as their own original creations. Blacks, meanwhile, were ridiculed as Negro musicians playing inferior coon music (Cleaver 1968; 79.80)

Inded one of my academic advisors (male of course) even directly told me that women's anthropology was not worth considering; few other professors, except a Marxist Africanist man and a Marxist woman, suggested that I even study either black or women's viewpornts; and only the latter suggested both.

If courses to the various "minority studies" are at all avilable to students within sociology and anthropology departments, they are generally presented as electives- subjects that students are free to study but do not necessarily have to master or take too seriously. Furthermore, minority students experience frequent indirect or even direct hazing and harassment. For example, women students and faculty report that the faculty in male dominated departments pay much more frequent complement to their clothes than to their work (which is minor compared to other problems). All minority students and faculty are subject to verbal and physical abuse. Finally, when certain black leaders have become too threatening then the machines of the media and state are mobilized to silence them. I give a rather lengthy quote by Eldridge Cleaver [one of the more militant spokespersons of Afro-Americans, I will abmit] not only to illustrate my point, but because the same methods are used by Euro-American interests to passivate people in the Third world.

One tactic by which the rulers of America have kept the bemused millions of Negroes in optimum subjugation has been a conscious systematic emasculation of Negro leadership. Through an elaborate system of sanctions, rewards, penalties, and persecutions-with, more often than not members of the black bourgeoisie acting as hatchet men-any Negro who sought leadership over the black masses and refused to become a tool of the white power structure was either cast into prison, killed, hounded out of the country, or blasted into obscurity and isolation in his own land and among his own people. His isolation was assured by the publicity boycotts alternated with 
character assassination in the mass media, and by the fratricidal power plays of Uncle Toms ${ }^{5}$ who control the Negro community on behalf of the white power structure. The classic illustrations of this quash the-black-Militant policy are the careers or Marcus Garvey, W.E.B. DuBois [sic], and Paul Robeson.

Garvey who in the first quarter of this century sparked a black mass movement based in America but international in scope and potential, was caste into federal prison and then exiled to England. (The sociologist) W. E. B. DuBois, one of the intellectual giants of the modern world, was silenced and isolated in America as viciously and effectively as the racist regime in South Africa has silenced and isolated such leaders of the black masses as Chief Albert Luthuli, or as the British, in Kenya, once silenced and isolated Jomo Kenyatta. After attempts to caste him into prison on trumped-up charges had failed, DuBois went into exile in Ghana and later renounced the bitter citizenship of the land of his birth.

Paul Robeson was at the apex of an illustrious career as a signer and actor earning over $\$ 200,000$ a year, when he began speaking out passionately in behalf of his people, unable to balance the luxury of his own life with the squalor of the black masses from which he sprang and of which he was proud The response of the black masses to his charisma alarmed both the Uncle Toms and the white power structure, and Paul Robeson was marked for destruction. Through a coordinated effort, Robeson became the object of economic boycott and character assassination.
Broken financially, and heartbroken to see black Uncle Toms working assiduously to defeat him and keep their own people down, Robeson's spirt was crushed, his hea!th subverted, and his career destroyed.

By crushing black leaders, while inflating the images of Uncle Toms and celebrities from the apolitical world of sport and play, the mass media were able to channel and control the aspirations and goals of the black masses [Cleaver 1968:88].

In academia, a method that these alternative voice have been silenced is that the "minority" viewpoiots are addressed from within their own separate disciplines such as of American, Women's, Native American or Hispanic studies departments. While having separate departments provides a refuge from a white male-dominated world, it also means that it is even more difficult for the minority ideas to challenge, transform and merge with the dominant ideas. Consequently, in regard to Black Sociology in particular, most students in sociology and anthropology pass through their entire course of study without ever being introduced to the work of great names such as W. E. B. Du Bois, Franklin Frazier, Charles Johnson, St. Clair Drake or Oliver C. Cox They nevar come to know that in his study, The Philadelphia Negro, for example, Du Bois (1899d) pioneered ethnographic participant observation and the survey method. They are never introduced to the rich, unanswered, one-sided dialogue in which these and subsquent scholars engaged with the mainstream white sociological tradition.

Although this dialogue- a dialogue in which one of the voice is suppressed- is called 'black' sociology, it is much more encompassing than the white male dominated social sciences which present themselves as the entire disciplines of anthropology or sociology. Always for the Afro-American, 
Woman, Hispanic and Native American in the United States, an aspect of their scholarship has necessarily been the working out their relationship to the society and scholarly discipline with which they are part yet which does not recognize or accept them or their viewpoint as legitimate. For the mainstream white male on the other hand his problem has just been one of formulating and presenting his view of society according to scientific principles and terms, while begrudgingly and selectively allowing black and other minority voices to emerge only at times when pressures coursing through the society became too strong to resist. And even when these voices are allowed to emerge, they are generally tempered to make them acceptable to ruling class viewpoints or co-opted to serve these ruling class interests against the very people who created them.

Regarding ethnography In particular, not only have minority voices been silenced in scholarship, but minority positions within the societies studied are ignored or silenced. Ethnography generally presents generalized pictures of societies from the viewpoint of high status, high class, high caste and high stetus males. The problems which have been framed as legitimate subjects of study further direct people away from the problems of the lower classes and the oppressed. For example, among foreign women doing work in Nepal, the scholarship is very often as nearly regressive and patronizing towords women as that of men. Class interest thus asserts itself over a gender one. Regarding Afro-American or low-class anthropologists and sociologists-male or female-I know of none who are working in Nepal. This in part because there are few of them, and those individuals are forced to confront their problems right at home.

Due to their disadvantaged position and low status within both their profession and the sociaty, Afro-American sociologists were combining theroy and practice lorg before the word praxis become fashionable in mairstream social science. Simply in trying to do their scholarship, the AfroAmerican sociologists were forced to confront their own personal and group conditions and status within the society. This forced them (and other minorities) from the outset to combine theory ane practice, and objectivity and advocacy.

... for the social sciences and the humanities, race "the problem" penetrates the very work itself, and there is no wey out of the dilemma save to fuse into the work itself one's commitment to one's people and one's commitment to the "objective truth" of scholarship and the "obiective standards" of enduring art.

Given the depth and pervasiveness of racism in the United States, if a man or a women is a historian and black, than he or she is compelled to work out a distinctive role balance between scholarship and advocacy, between creativity and commitment.

...Whatever the gross unfairness of the racial pressures on the black play wright or essayist, the work itself must still come first and stand on its own; it is almost inevitably (though not necessarily) "about race" yet it cannot be exclusively assessed "according to race"..." when his work is recognized it is usually pointed to as the work of a Negro. $\mathrm{He}$ is a competent Negro sociologist, an able Negro economist, an outstanding Negro historian. Such recognition is as much the product of the racist mentality as the Negro restrooms in the Montgomery airport " 6

Judgement of the work itself-implied in such phrases as "a competent sociologist," "'an 
able economist" - would constitute the essential standard if other things were equal that is, if the society in general had been guaranteeing a rough equality of access to scholars and writers irrespective of skin color. Since that has not been the cass, and still is not, despite rapid changes in the direction of equality of opportunity, the racial designations are going to be applied by the dominant group in any case, whether from motives of discrimination, condescension patronage, mechanical liberalism, or whatever. Therefore, the black social scientist owe it to himself and tho black community to fashion his own sense of balance inside the work itself - objective, scholarly analysis of the racial situation, its history and its structure, and passionate advocacy of freedom, justice, and group identity

The consequence of the need to combine scholarship and advocacy is that Afro-American work from its inception pioneered in a very personal way the same reflexive trend that the dominant tradition of sociologists and anthropologists are now discovering and developing as their own in a detached academic sort of way (primarily through often watered down reinterpretations of the works of Marx, Engels, Gramsci and their epigones). The consequence of having to combine theory and practice has meant that many Afro-American sociologists have left sociology and engaged in more direct and practical kinds of work, while at the same time publishing a rich corpus of material from their experience.

Typically, even now, only a few at the "radical" end of the spectrum of the social sciences are entering into dialogue with the Afro-American sociological tradition. Yet, AfroAmerican reflexivity has long had the mainstream tradition in its purview. Thus whereas the mainstream social sciences offer just a partial view of the human experience in the U. S. and the world, Afro-American sociology must include both sides. AfroAmerican sociology has not meant just a study of racs, it has meant a study of the relationship of black to whites, of oppressed to oppressor, of the relation of the various oppressed among themselves, of the peoples of the world to European and American expansion, and of the conditions generally which have given rise to relationships in which people are oppressed according to the color of their skin and other social categories. Indeed, due to its partial viewpoint, mainstream sociology should be the one prefixed with "white male" - the oppressor's representation of the world.

Better yet, however, is that the significant voices of Afro-Americans assert themselves and be acknowledged in theoretical discourse, allowing real, radidel alternatives to be brought to the fore in scholarship and society For scholars in Nepal; it is essential not to accept sociology and anthropology according to the dominant self-definitions as handed from western countries, especially since the most powerful voices most easily transfer themselves to Nepal, however inappropriate may be their grafts ${ }^{7}$ The experiences of Afro-Americans and other colonized peoples of the world (including women) have been suppressed or devalued. Yet these voices will provide a multidimensional understarding of sociology and the world which they take as their subject.

Generally the minority western scholars have much more in common with the great majority of the people of Nepal since they are in an analogous position towards western power interest as the great mass of the people in Nepal and the rest of the Third world. Their studies provide an alternative model from that of the mainstream bikas (development) ideology which has had such disastrous consequences in the bankrupted continents of Asia, Africa, Latin America and Eastern Europe, as well as for the poor of the United States and Western 
Europe (and, needless to say, for the people of Nepal during the panchayat period in Nepal). And as Du Bois (1985 a: 241-2) points out, initiative for transformation of the world will come from those belonging "to the disinherited of modern culture" and not from "from those who now so largely own and rule the world"

\section{W. E. B. Du Bois}

Of the most prominent early Afro-American sociologists, including Charles Johnson, Frazier, St Clair Dreak Horace Cayton and Oliver C. Cox. Dr W. E. B. Du Bois stands out as one of the greatest sociologists who ever lived. Throughout his ninety-five year life, until he died in 1963 in Ghana, he analyzed American society and world events in acute detail, Living his words in the last sentence of the quote at the top of this paper, he cantinued to change his role and analytic perspective as the situation of the world changed arcurd him and his own experience grew.

In the decade prior to 1895, he studied at Fisk, Harvard and Berlin "under the tutelage of an array of scholars whose combined distinction touched few, if any other young Americans". (Broderick 1974,3) In 1896, he engaged in his more than a yearlong participant observation study of Philadelphia AfroAmericans (mentioned above).

"Using a lengthy questionnaire, he did a house-to house survey of all the black families in the ward. He compiled voluminous data on patterns of migration into and within the city, family structure, income, occupations, property holdings, social stratification, black community institutions, politics, pauperism The data gave a dismal portrait of unemployment, job discrimination by both employers and trade unions, wretched housing, family breakdowns, substantial criminality, and widespread health and hygienic problems. On the other hand, Du Bois's monograph was a brilliant description of the contours and functioning of the black community, its institutions, and its mechanism for social survival and advancement" (Rudwick 1974 28).

He addressed the color bar, by which Afro-Americans were prevented from entering mainstream laboring occupations; even the quarter of the population engaged in business were being pushed out by white immigration and large-scale capital. He showed how the social problems, which characterized blacks, reflected economic problems. He directly tied together economic status and family structure. And he identified three factors responsible for the "pressing series of social problems" of blacks in Philadelphia: the legacy of slavery, influxe of new migrants from a changing rural economy in the Southern states, and "the environment in which a Negro finds - the world of custom and thought in which he must live and work, the physical surroundings of house and home and ward the moral encouragements and discoulagements which he encounters".

This latter statement was made more than a half century before the anthropologist Oscar Lawis coined the term "culture of poverty". Similarly. his emphasis on "the impact of discrimination of the personalities and aspirations of black men and women" (Rudwick 1974:32) foreshadowed studies in culture and personality. And "in stressing the importance of migration, Du Bois also prefigured a subject that would interest later sociologists studying black urban communtities" (I bid: 32) Unlike Oscar Lewis or the culture and personality school, Du Bois placed his analysis in a broad social, econonical, political ideological and historiacl context.

He approached his subject in terms of a class analysis, which included four social "grades" or classes: upper class or "aristocracy" (one-tenth) "respectable working class" (a half) "the poor" (a third). and the group with criminal records $(6 \%)$. 
His identification of great social variability knocked down the dominant racist stereotype which conceived of all black in terms of the last smallest group. It also differed very much from the generalizing, normative tendency that characterizes much of cultural anthropology even today. Compare the following statement to such characterizations of peop'e described in terms of Magar, Gurung, Newar, Nepali or Japanese and American culture, which slips so easily from the lips of so many anthropologists.

"There is always a strong tendency ... to consider the Negroes as composing one practically homogeneous mass. This view has of course a certain justification: the people of Negro descent in this land have had a common history, suffer to-day common disabilities, and contribute to one general set of social problems. Yet, if the numerous statistics supplied in the volume 'have emphasized any one fact it is that wide variations in antecedents, wealth, intelligence, and qeneral efficiency have already been differentiated within this group ( $\mathrm{Ou}$ Bois 1999 : 309)" [Rudwick 1974 : 34]

In addition to writing "a conscienticus and perceptive sociological study Du Bois, in his combination of theory and practice, took the role of social reformer. On the one hand, he called for "a radical change in public opinion" from the whites. On the other, he saw that the greatest responsibillty for change lay with the black people themselves: in protest in, economic and social cooperation in unity of all classes of blacks.

From 1897 to 1914 he attempted to begin a major series of sociological studies of blacks from a position at Atlanta University. Despite extremely poor funding of less than $\$ 500$ a year. he was able to produce a large series of monographs, providing a storehouse of information from the period and initiating for the first time serious sociological research into
Afro-Americans. Again, his work combined an emphasis on social reform along with scholarly description. However, there was little iriterest in his work, and saw that the pressing problems demanded that he leave academia. Nevertheless, through the rest of his life he continued to publish a major book every five years, along with an immenese number of articles addressing events and conditions in the world.

An example of the impressive depth and breadth of his analysis, with the Afro-American perspective expressed in all its breadth and intricacy is Du Bois' 729 page work, Black Reconstruction in America 1860-1880 published in 1935. In this work he analyzes the mostly unsuccessful struggle of the blacks to free themselves from slavery and gain full citizenship right during and after the American Civil War. He destroys the myth of American history that Abraham Lincoln freed the slaves, showing rather that the black slaves themselves went on a mass strike on the plantations during the Civil War (1860-65), either refusing to work or fleeing to the initially unreceptive United States armies. Lincoln's proclamation of freedom for the slaves was merely a recognition of what the blacks had already taken in their own hands, and it was forced upon him by the need for 200,000 black Americans to man the U. S. armies in the face of the growing resistance of white workers to a fight which they increasingly saw to be a war benefitting capitalists.

In the aftermath of the Civil War, the northern capitalists (still represented by the Republican Party) combined with the large southern landowners (repsesented by the Democratic Party) who they had just defeated, in order to destroy the labor movement in the United States by dividing white from black. The recently freed blacks in the Southern United States were thrown back into new kind of slavery based on share-cropping, insuring the renewed supply of cheap raw materials for northern United States factories. The great masses of white poor in the south, who agian were unemployed because they could not compete against the black laborers, were recıuited into the Klu 
Klux Klan terrorist organization to immobilize the Afro-American and suppress their freedom movement. This of course made the white laborer's position all the worse vis-a-vis the large landholders and capitalists. In the western states of the United States, large capitalists destroyed the small free holding peasant farmer. In the industrial north, the large capitalists co-opted the labor movement, by making the white workers become obsessed with protecting their high-paid jobs from Afro-Americans and women, rather than directing their demeads at the capitalists. The result was to deeply effect not only the future development of the United States, but the trajectory of develoment throughout the world to this very day.

America thus stepped forward in the first blossoming of the modern age and added to the Art of Beauty, gift of the Renaissance, and to the Freedom of Belief, gift of Martin Luther and Leo X, a vision of democratic self-government: the domination of political life by the Intelligent decision of free and self-sustaining men. What an idea and what an area for its realization-endless land of richest fertility, natural resources such as Earth seldom exhibited before, a population infinite in variety of universal gift, burned in the fires of poverty and caste, yearning toward the Unknown God, and self-reliant pioneers, unafraid of man or devil. It was the Supreme Adventure, in the last Great Battle of the West, for that human freedom which would release the human spirit from the lower lust for mere meat, and set it free to dream and sing.

And then some unjust God leaned, laughing over the remparts of heaven and dropped a black man in the midst.

It transformed the world. It turned democracy back to Roman Imperialism and Fascism, it restored caste and oligarchy, it replaced freedom with slavery and withdraw the name of humanity from the vast majority of human beings.

But not without a struggle. Not without writhing and rending of spirit and pitiable wall of lost souls. They said: slavery was wrong but not all wrong; slavery must perish and not simply move; God made black men; God made slavery, the will of God be done; slavery to the glory of God and black men as his selvants and ours; slavery as a way to freedom- the freedom of blacks, the freedom of whites; white freedom as the goal of the world and black slavery as the path there to. Up with the white world, down with the black .

Then came this battle called Civil War, beginning Kansas in 1854, and ending the presidential election of 1876- twenty awful years. The slave went fiee, stood a brief moment in the sun; then moved back again toward slavery. The whole weight of America was thrown to color caste. The colored world went down before England France, Germany, Russa, Italy and America. Anew slavery arose. The upward moving of white labor was betrayed into wars for profit based on color caste. Democracy died save in the hearts of black folk.

Indeed, the plight of the white working class throughout the world today is directly traceable to Negro slavery in America, on which modern commerce and industry was founded, and which persisted to threaten free labor until it was partially overthrown in 1863. The resulting color caste founded retained by capitalism was adopted, forwarded and approved by white labor and resulted in subordination of colored labor to white profits the world over. Thus the majority of the 
world's laborers, by the insistence of white labor, became the basis of a system of industry which ruined democracy and showed its perfect fruit in World War and Depression. And this book seeks to tell that story [Du Bois 1935-301.

While addressing the history of the United States in this book, W. E B. Du Bois addressed significance of what was happening in the United States and Europe for the countries of the Third World in an immense body of subsequent works.

All over the world, the organized economic power of Europe driven by the new capitalism and implemented by the new science and technique, fell upon ancient static cultures, ripped them apart. left them in helpless ruin and built a mass of poverty, ignorance and disease, that contrasted so painfully with what Europe was accomplishing, that Europe not unnaturally corcluded that everything European was right and progressive, and everything Asiatic and African was decadent and barbaric Then it was that gradually Europe, despite her bitter struggle not to admit it, began to realize that much she had ruined or distorted was necessary to real civilization; and that while Asia and Africa were at present too prone and helpless to reform an ailing world, nevertheless Europe was likely to commit suicide after all her magnificent effort, unless she proceeded to rid herself of the worst of the consequnces which she had herself evoked.

Europe today with an accumulation of knowledge of this universe, built up laboriously and triumphantly over five long centuries, is unable to redeem mankind because most men, bound mind and body in the shackles of European profit, afe too ignorant to appreciate and help preserve and extend this priceless treasure. Rolling in unprecedented wealth and capable by her miraculous technique, of indefinitely extending and multiplying this wealth, Europe finds herself bankrupt because of wars waged to defend this wealth and make more; and weighed down in every part of the world by an array of sheer sordid poverty on the part of the very people, whose work ringtly directed, would give every human being a decent living. With a knowledge of the human brain and body capable of prolonging life twenty years beyond the biblical three-score-and ten, Europe faces a world swept by preventable disease among colonial Millions, her own birthrate declining because of luxury and indulgence, followed by the deliberate murder of ten million of her most promising young men in desperate effort to save that world which she has created [ $\mathrm{Ou}$ Bois 1985a :239-240].

Du Bois sees the solution to the great ills that have been brought onto the world as laying in bringing the broad participation of the great masses of people into running the world. In this regard he has much to say for the present endeavor to develop democracy in $\mathrm{Nepal}$

..When it comes to democracy, the placing of political power in the hands of the mass of intelligent people there are many who regard this step as philanthropy and withal dangerous philanthropy. They think of the right to vote as a concession from the cultured elite to the inexperienced and irresponsible mass, with the threat of slowing up or even attacking civilization. Such retrogression has occurred and may occur in the progress of democracy; but the vaster 
possibility and the real promise of democracy is adding to human capacities and culture from hitherto untapped sources of cultural variety and power. Democracy is tapping the great possibilities of makind from unused and unsuspected reservoirs of human greatness. Instead of envying and seeking desperately outer and foregin sources of civilization, you may find in these magnificent mountains a genius and variety of human culture, which once released from poverty, ignorance and disease, will help guide the world. Once the human soul is thus freed; then and only then is peace posible. There will be no need to fight for food, for healthy homes, for free speech; for these will not depend on force, but incresingly on knowledge, reason and art [1bid 242-3].

This discussion is a timely today for Nepal and the world as it was when it was written when Eurcpe was emerging from the midst of a terrible war. This war had cams to Europe because democracy had been suppressed as the large corporation which had emerged in the last part of the 19 th and beginning of the 20 th centuries were threatened by mass worker movements across Europe and the United States in the 1920 and 1930s. These busineses preferred to put state power into the hands of facists who directed the economics of European countries towards their needs than give power over to the people Immense profits were made in the gigantic war which was than needed to destroy the facist regimes which had been slipped into power by these corporations. Subsequent to the War, Du Bois's plea was ignored, and the world again is on the edge of an immense crisis being precipitated by immense international debt, environmental destruction, a continual preparation for war, corporate greed, and the continued disenfranchisement of the great masses of people.

\section{A Selocted and Partial Bibliography}

Broderick, Francis L.

1974 W. E. B. Du Bois: History of an Intellectual. In Black Sociologists: Historical Contemporary Perspectives, James E. Blackwell and Morris Janowitz, eds. pp. 3-24 Chicago: University of Chicago.

Cox. Oliver C.

1942 The Modern Caste School of Race Relations. Social Forces, 21:218-26.

1944 The Political Class. Bulletin: Society for Social Research (January).

1944 Class and Caste. Journal of Negro Education, 13: 139-49.

1945 An American Dilemma (Critique of Gunner Myrdal). Journal of Negro Education, 15: 132-48.

1945 Race and Caste: A Distinction. Journal of Sociology 50: $360-68$.

1945 Estates, Social Classes, and Political Classes. American Sociological Review, 10: 464-69.

$19 \$ 5$ Lynchings and the Status Quo. Journal of Negro Education 14: 57688 .

1946 The Nature of the Anti-Asiatic Movement on the Pacific Coast Journal of Negro Education 15: 603-14.

1947 Color Prejudice: A World Problem. The Aryan Path (Bombay, India), June

1947 Modern Democracy and Class Struggle: Journal of Negro Education 16: 156-64.

1948 Caste, Class and Race. Now York: Monthly Review Press.

1950 Max Weber on Social Stratifications. A Critique American Sociological Review 15: 221-27, 
The Medieval City: Its Relationship to Modern Culturé. Mid/West Journal 7: 165-75.

1964 Capitalism as a System.

1959 The Foundations of Capitalism. Philosophical Library.

1962 Capitalism and American Leadership.

1974 The Problem of Societal Transition. American Journal of Sociology 79: 1120-33.

1974 Jewish Self-Interest in Black Pluralism. Sociological Quarterly 14: 183-98.

1876 Race Relations: Elements and Social Dynamics. Detroit Wayne State University Press.

1987 Race, Class, and the World System: The Sociology of Oliver C. Cox. New York: Monthly Review Press.

Drake, St. Clair, and Horace Cayton

1945 Black Metropolis. New York: Harcort, Orace.

Du Bois, W. E. Burghardt (much omitted here, include novels and poems)

1896 The Suppression of the African Slave Trade to the United States of America, 1638-1870, Harvard Historical Studies no. 1; New York; Longmans, Green.

1898 The Negroes of Farmville, Virginia: A Social Study. U. S. Department of Labor Bulletin 3 (January): 1-38.

1899a The Negro in the Black Belt. U. S, Department of Labor Bulletin 6 (May): 401-17.

1899b The Philadelphia Negro: A Social Study. Philadelphia: University of Pennsylvania.

1901 The Negro Landholder of Georgia. U. S. Department of Labor Bulletin 6 (July): 657-777.

1903 The Souls of Black Folk: Essays and Sketches Chicago: A. C. McClurg and Co.
1905 The Black Vote of Philadelphia. Charities 15 (October 7): $619-21$.

1902 The Negro Artisan Atlanta: Atlanta University Press.

1912 The Negro-American Artisan. Atlanta University Press.

1921 Darkwater. Voices from within the Veil. New York: Harcourt, Brace and Co.

1930 Africa: Its Place in Modern History (no. 1152. Girard, Kans.: Haldeman-Julius.

1935 Black Reconstruction in America, 1860-1880. New York: Meridian Books.

1939 Black Folk Then and Now: An Essay in the History and Sociology of the Negro Race. New York: Henry Ho!t and Co.

1940 Dusk of Dawn: An Essay toward an Autobiography of a Race Concept. New York: Harcourt, Brace and Bo.

1945 Color and Democracy: Colonies and Peace. New York: Harcourt Brace and Co.

1985a Colonialism, Democracy, and Peace after the War (Summer 1944). In Against Racism: Unpublished Essays, Papers Addresses, 1587-1961, Herberr, ed pp. 229-224. Amherst: The University of Massachussets Press

$198^{\circ} \mathrm{b}$ The Negro and Social Reconstruction (1936). In Against Racism: Unpublished Essays, Papers, Addresses, 19871961, Herbert Aptheker, ed. pp. 229-224. Amherst: The University of Massachussets Press.

Frazier, E. Franklin

1949 Race Contacts and the Social Structure. American Sociological Review 14 (February): 1-11.

1947 Sociological Theory and Race Relations. American Sociological Review 12 (June): 265-71.

1956 The Negro in the United States. Rev. ed. New York. Macmillan, 


\section{Robbins, Richafld}

1974 Charles R. Johnson. In Black Sociologists Historical and Contemporary Perpectives, James E. Blackwell and Morris Janowitz, eds. pp. 56-84. Chicago and London. The University of Chicago Press.

Rudwick, Elliot

1974 W. E. B. Do Bois as Sociologist. In Black Sociologists: Historical and Contemporary Perspectives, James E. Blackwell and Morris Janowitz, eds. pp. 25-55 Chicago and Landon: The University of Chicago Press.

${ }^{1}$ See particularly the articles discussing the development of the department and discipline of anthropology. In volume 1, see Dor Bahadur Bista, "Nepal School of Sociology/Anthropology," pp. 6-11, Krishna B. Bhattachan, "Sociology and Anthropology Curriculum and the Needs of Nepal". pp. 11-28, and "Romanticism and 'Development' in Nepalese Anthropology", pp. 29-45. In volume II, see Om Gurung, "Sociology and Anthropology: An Emerging Field of Study in Nepal", pp. 4-12 and Bishnu Bhandari, "The Past and Future of Sociology in Nepal", pp. 13-23. The editorship of the two journals are also cases in point.

2Jurgen Habermas, Knowledge and Human Interests, London (1971).

${ }^{3}$ This is comparable to the domination of Nepali Society by Brahmanic ideas, which for the most part represent the interests of the ruling class, although not all high caste individuals belong to the ruling class. Unlike in Europe, caste categaries originally developed in combination with the development domination of landed property over the society in its various stages. In India especially it has been taken up by the capitalists- both foreign and domestic- 10 secure the hold of capital over the society, and thus continues with a somewhat different content. The category of race, however, developed with capitalism, entirely replacing the concept of "estates", which had characterized the rule of landed property in Europe in preceding ages. Given quite historicol trajectories of the development of landed property and the state in Western Europe and South Asia, neither the terms "estate", "guild", nor "race" are interchangeable with caste, even if each shares certain common features with caste.

From a functional perspective (i. e., in terms of imposing the rule of a certain class, dividing the labor force, enforcing a certain division of labor according descent, controlling marriage) though not developmental one, caste is more a subset of race being a manifestation of caste. The so-called "caste school of race", which presented race as caste, attempted to give race and objective existence in the United States by equating it with caste. The flaw was that caste also lacks an objective existence, and can just as well be the object of the criticism which was directed at this theory by sociologists such as Oliver C Cox.

In an article in preparation, I am showing developmentally and functionally that caste and citizenship originally addressed the same problem of establishing a class rule of a small group of people over the vast majority of people by extension of kinship categories. Their differences are tied up with the particular historical conditions which framed the expansion of the city state from Mesopotamia into South Asia and Greece respactively.

${ }^{4}$ For example, the one Afro-American introduced to Nepali students in the course of study for their SLC examinations in Nepali as Booker T. Washington. Yel he is widely criticized by Afro-Americans for cornpromising the movement for human rights to the big business Interests which controlled the postCivil War United States. As this quote demonstrate his policy is basically the same as the supplied to third world countries generally, and thus it is no surprise that an American designed 
education system should eulogize Carver in young people's text books, while remaining silent about other more critical AfroAmerican viewpoints.

Above all. Mr. Washington had not the slightest doubt that the current organization of industry in the United State was normal and right; that capital was accumulated by thrift; that labor was rightfully bought and fed and that profits were rightly the result of buying the product of labor. He therefore proposed that the Negro take this path toward eventual equality working hard and skillfully to earn a living, and beyond that to accumulate in the hand of more thrifty and gifted individuals, enough capital to hire employees and make money. He expected that the black owners of property would thus gain recognition from other property holders and gradually rise in the scale of sociely. As a first step toward this new capitalism, Washington especially stressed landholding, wide-spread peasant proprietorship and even large-scale farming among Negroes.

'As a practical path toward these things, Mr. Washington's program included giving up of political rights, at least temporarily; the giving up of agitation for civil rights; and the insistence upon training young Negroes for farming and industry through industrial schools and a vocational program of education. This plan launched in 1895, and triumphant from that date until about 1910, was in reality an alliance with white capital and was rewarded by large contributions toward Negro education, especially to such schools as conformed to the Hampton and Tuskegee type. It was rightly regarded as a clever and far-sighted compromise which, if it would not solve, would at least peacefully postpone the solution of a baffling internal problem of race conflict" (Du Bois 1985b: 114).

5 "A black eager to win the approval of white and willing to coopsrate with them".
'John Hope Franklin, "The Dilemma of the Negro American Scholar", in Herbart Hill, ed., Soon One Morning; New Writing by American Negroes (New York: Alfred A. Knopf, 1966), p. 61

${ }^{7}$ The white-male view point dominates the major journals and books, reflecting both the dominance of this viewpoint over the discipline and the publishing houses. Furthermore, Nepali exchange students almost invariably go to departments dominated by white males, particularly those which are defined as prestigious I know of no Nepali students who have studied in the great Black oollages such as Howard, Fisk, or Atlante. I know of one person stucying at the Graduate Center of the City University of New York, which has a much more ethnically mix faculty and student body than more prestigious universities. A major reason, certainly, is that these universities have much lower operating budgets and may not be able to offer financing. Another reason, however, may be that these have been attributed lower status than white universities (by white scholars) and lack their prominence. Finally, a large portion of students from Nepal, like elsewhere, see their education as establishing them in privileged class positions and prestigious occupations in Nepal and the global political economy. From this standppint, schools built for the oppressed rather than the oppressor are much less desirable. If I seem critical here, I am sorry to say that it is just as much self criticism.

\section{$x$}

